\title{
Examining the Mechanism for the Transferability of Leadership Elements to Students: The Case of the Catholic University Institute of Buea (CUIB)
}

\author{
Maurice Ayuketang Nso \\ Department of Banking and Finance, Catholic University Institute of Buea (CUIB), Buea, Cameroon \\ Email: lordnso@yahoo.co.uk,mnso@cuib-cameroon.net
}

How to cite this paper: Nso, M. A. (2018). Examining the Mechanism for the Transferability of Leadership Elements to Students: The Case of the Catholic University Institute of Buea (CUIB). Open Journal of Leadership, 7, 155-167. https://doi.org/10.4236/ojl.2018.72009

Received: April 8, 2018

Accepted: June 11, 2018

Published: June 14, 2018

Copyright $\odot 2018$ by author and Scientific Research Publishing Inc.

This work is licensed under the Creative

Commons Attribution International

License (CC BY 4.0).

http://creativecommons.org/licenses/by/4.0/

\begin{abstract}
This paper recommends what could be a standard definition for the word "leadership", as it found out that there has been no standard way for defining leadership, and that others have defined leadership based on the leadership elements a leader has but failed to rethink that one could be a bad leader and as such the leadership elements could not be transferred (passed on) to heirs for the simple reason that no one likes bad things.
\end{abstract}

\section{Keywords}

Autocratic, Leader, Leadership, Leadership Elements, Perfect Leadership

\section{Introduction}

Leadership is one of the most comprehensively researched social influence processes in the behavioural sciences (Barrow, 1977; Nso \& Ngatchu, 2017). This is because the success of all economic, political, and organizational systems depends on the effective and efficient guidance of the leaders of these systems (Barrow, 1977). In an unpublished international conference paper, Nso and Ngatchu (2017) stated that, not only has CUIB been successful, as an Entrepreneurial University, but she has equally been able to pass on leadership principles and values to her students and alumni. Leadership is a skill used to influence followers in an organisation to work enthusiastically towards goals specifically identified for the common good (Barrow, 1977; Cyert, 2006; Plsek \& Wilson, 2001). Ronald (2013) posits that a leader's behavior is often emulated by subordinates because, leaders are perceived as attractive and credible models of nor- 
mative and appropriate behaviour, an action that is consistent with theories of social learning. In our organisations and society today, it is not enough to be a leader. It is ideal for leaders to pass on skills or elements to subordinates and/or followers. Universities and educational institutions are suitable grounds to transfer leadership skills to students as heirs of future organizational, economic and societal development and advancement.

\subsection{About CUIB}

The Catholic University Institute of Buea (CUIB), Cameroon, was approved as a non-profit making university in two separate letters. The authorisation to create CUIB on 09/01/0194 of 11 June 2009 and the authorisation to start were signed by the Minister of Higher Education decision No. 10/02173/N/MINSUP/DDES/ ESUP/SAC/NJE/EBM dated $26^{\text {th }}$ of May 2010. These two decisions gave the university a legal status as an international institution which started operations in 2010. The primary purpose of the university is to train professional servant leaders with moral and spiritual values so that they may impart their communities positively.

In June 2011, the university created the business and research park as a legal entity of its own recognised by Cameroon laws No. RC BUC.2031-B023 with the name CUIB Centre for Entrepreneurship, Research and Innovation (CERI) now called Center for Entrepreneurship and Innovation (CEI). In December 2014, the Catholic University Institute of Buea Sport Academic (CUSA) went operational with authorisation No. 1106/G37/C84/VOL II/SAAJP with the aim of assisting young and talented Cameroonians in various disciplines of sport like football, volleyball, basketball, handball etc. (CUIB, 2015-2016 Bulletin).

The Proprietor, Founder, Promoter and Chancellor of CUIB is Bishop Emmanuel B. Bushu of the Diocese of Buea. At the top of the university, management is charismatic and visionary Rev. Fr. George Jingwa Nkeze as the President and Pro-Chancellor. He drives the implementation of the university leadership strategy and is responsible for ensuring that Catholic Christians and entrepreneurial values are passed to the students. CUIB is relatively a young university, seven years old as at now, and it is the first Entrepreneurial University in Cameroon which is also following the typical America style of a 4-year undergraduate education system. Though a Catholic university, it is non-discriminatory. Its doors are open to all those who are searching for knowledge, irrespective of their nationality, religion, sex, race and language. Stakeholders enrolled in CUIB belief, know and have the awareness that they are enrolled in a city of saints and scholars. The Catholic University Institute of Buea (CUIB) is an affiliate of the Association of Catholic Colleges and Universities (ACCU).

\subsection{Problem Statement}

The best way to define leadership is difficult. Look up "Leadership Definition" in a Google search and in $0.44 \mathrm{sec}$ you get $269,000,000$ results. Despite this massive 
number, actually the definition is not the issue it is the transfer of leadership skills to followers that is the hardest part. Inherently, defining leadership means understanding yourself from an inward perspective as well as translating your own tendencies, strengths and approaches into the way you interact, communicate and influence others" Mark Miller, VP of Marketing, Emergenetics International. ${ }^{1}$ This paper exudes that there is a difference between leadership elements and the definition of what leadership is? It examines that it is the ability of someone to transfer or pass-on the leadership elements to heirs (students) that makes one a leader and as such leaders could be classified as perfect, good or bad. And rather a genuine scale for the grading and classification of leaders based on the leadership elements they possess and demonstrates does not exist.

\subsection{Research Questions, Objective and Significance of the Study}

There following questions shall be examined:

1) Using the available mechanism that an academic institution has what leadership elements can she transfer to students or heirs?

2) Is there a standard definition for the term leadership?

The main objective of this paper is to examine CUIB's mechanism for the transferability of Leadership elements to students. An auxiliary objective is to recommend a definition for the word leadership based on the study.

The scope of this work is limited to CUIB. The reason for this choice is that CUIB is the very first entrepreneurial university in Cameroon. The significance of this study is to help to expose such that others can emulate the various mechanisms or channels an academic institution can use to transfer leadership elements to students.

\subsection{Definition of Key Term}

Leadership: Leadership is a privilege and a responsibility that demands a good deal from those who practice it, whether formally or informally. Leadership is a skill used to influence followers in an organization to work enthusiastically towards goals specifically identified for the common good of all stakeholders (Barrow, 1977; Cyert, 2006; Plsek \& Wilson, 2001). Leadership should be the humble, authentic expression of your unique personality in pursuit of bettering whatever environment you are in.- "Katie Christy, founder, Activate Your Talent. Business News Daily viewed leadership as the ability of an individual to establish a following among other individuals or teams. A leader is one who sees more than others see, who sees farther than others see and who sees before others see."-Leroy Eimes, author and leadership expert. "A leader takes people where they want to go. A great leader takes people where they don't necessarily want to go, but ought to be."-Rosalynn Carter, former first lady of the United States.

Leadership Elements: These are skills, abilities or qualities that leaders pos-

${ }^{1}$ Miller, M. The 5 Ways to Define Leadership. Emergenetics International. https://www.emergenetics.com/blog/5-ways-define-leadership/ 
sess and demonstrate easily.

\section{Literature Review}

Two major concepts are reviewed; leadership and leadership elements.

\subsection{Leadership Point of Views}

Leadership theories attempt to explain and organize the complexity of the nature of leadership and its consequences (Bass \& Bass, 2008). Leader's effect on organization's values is not a new idea. Since people are social beings who are affected from other people, leaders are the important role models in order to foster a favorable ethical climate. Several scholars have presented models of organizational leaders' influences on organizational culture and climates. According to the research findings, there exists a positive relation between leadership and ethical climate (Jose \& Thibodeaux, 1999; Dickson et al., 2001; Schminke et al., 2005; Neubert et al., 2009; Mayer et al., 2010; Elçi et al., 2013). Mendonca (2001: p. 268) noted that, "leaders are responsible for the organization's moral climate that, in effect, reflects the moral development of the leader" and Aronson (2001: p. 245) states that, "ethical behavior on the part of the leader would appear to be a necessary condition for the establishment of an ethical organization". Treviño et al. (2000: p. 128) discuss the importance of a leader's reputation for ethical leadership, noting that "values are the glue that holds things together, and values must be conveyed from the top of the organization" a view that Thornton (2013) also upholds. Dickson et al. (2001) suggest that the critical determinant of ethical climate is the leader's ethical behaviour. Some researchers (Sims, 2000; Sims \& Brinkman, 2002) draw on Schein (1985) to describe how leaders shape and reinforce the ethical climate of an organization. A leader's ethical approach affects an organization's ethical climate (that is role modeling, rewards, selection, and communication), they all agree that leaders have substantial power to create and maintain ethical norms and processes, and to create a particular kind of ethical climate (Schminke et al., 2005). (Thornton, 2013) notes that, the key to having an ethically-run company is employing morally upstanding leaders.

Great leaders create a vision for an organization, articulate the vision to the followers, build a shared vision, craft a path to achieve the vision, and guide their organizations into new directions (Banutu-Gomez \& Banutu-Gomez, 2007; Kotter, 2001; Parris \& Peachey, 2013). According to Schneider (1987), the most important part in building an organization with a legacy of success is the people in it, which includes the followers (i.e., employees and volunteers) as well as the leaders and students should not be excluded in the set. Students are future leaders of tomorrow and as heirs they are the agents of future societal development and advancement. Ronald (2013) confined that a leader's behavior is often emulated by subordinates because leaders are perceived as attractive and credible models of normative and appropriate behavior, an action that is consistent with theories of social learning. 


\subsection{Leadership Elements Transferred}

What is leadership? Each of us believe we have a good idea about what it means to be a good leader, but when it comes to defining the concept, the picture is not so clear. For some, leadership is motivation, for others, it equals results, for others it is inspiration. Game Learn $(2016)^{2}$ defined Leadership based on 10 common elements. These elements are:

1) Vision: Leading means having a vision and sharing it with others. When you inspire others, it is possible to share a common goal to direct the efforts and dedication of the entire team.

2) Motivation: Leaders know how to motivate better than anyone else; it is one of their main functions as people managers. Motivation helps leaders' channels the energy and professional potential of their coworkers to achieve desired objectives.

3) Serving: The leader is at the service of the team, and not the other way round. Leader should support group members, provide tools to do jobs, recognize efforts and pay attention to group members in order to correct bad habits.

4) Empathy: One of the basic qualities of any leader seeking success is precisely emotional intelligence, that ability-often innate-makes leaders put themselves in the place of others, understand their concerns and solve problems. Leaders know the secrets of their businesses better than anyone so can easily empathize with customers and members of their teams.

5) Creativity: Good leaders create an environment that will encourage all the members of their team to develop skills and imagination, to contribute to the common project and vision of the company.

6) Thoroughness: A good leader sets the bar high for their people, because they want to reach the goals and make the best of their teams. In addition to this thoroughness, the leader should know how to listen to know the needs of the people and see how to provide for them.

7) Managing: The leader is the forefront to lead and guide their team throughout the whole process until the goal is reached. That is being "torchbearer", and being able to step back and make their team take the initiative to give others the chance to develop personally and professionally. Pure management focuses on the tasks, real leadership focuses on the people.

8) Team building: True leadership is about working in a team to reach a common goal. People management is a difficult tasks faced by leaders. Successful teams will have trust in their workmates and people and get better results.

9) Taking risks: The leader is the one responsible for taking the risks that others are not willing to take. They are confident enough to make a decision, and if they make a mistake, the leader must have the courage to rectify, assume their guilt and take the right path, without blaming it on the team. Good leaders know how to get ahead of their peers on time, they see opportunities where others can't and know how to spread the enthusiasm for their vision to try to

${ }^{2}$ https://www.game-learn.com/what-is-leadership-ways-to-define/. 
make it real.

10) Improving: True leadership seeks continuous improvement. Leaders have the ability to turn the people in their teams into stars, people who have improved and developed their skills through the influence of their leader.

\subsection{Others Thoughts on What Constitutes Leadership Elements}

Others have viewed leadership elements in similar or different manner from game learn proposal. Of course this is obvious; Leadership is subjective though its foundation stems from one thing: the ability of an individual to establish a following among other individuals or teams. This is because every leader has his or her own style and strategy. To start recently, Post $(2017)^{3}$ asked current leaders and founders to explain what leadership means to them. Their views totaled 11 points on leadership elements: 1) the pursuit of bettering your environment, 2) Knowing your team and yourself well, 3) Giving people the tools to succeed, 4) Open, authentic and positive influence, 5) Clarity, confidence and courage, 6) Building consensus and common goals, 7) Being the solution to problems, 8) Helping others achieve the impossible, 9) Building the next generation of leaders, 10) Building followership and 11) Actively listening.

On the other hand Murphy $(2015)^{4}$ detailed 4 Essential Elements of Successful Leadership as: 1) Transparency, 2) Learn from failure, 3) Trust, and 4) Confidence. Mark Miller stated five ways that you as a leader can bring greater focus and clarity to leadership approach: 1) Trust, 2) Action, 3) Perspective, 4) Focus and 5) Vision. While Bell (2016) stated 1) Ability to delegate task, 2) Excellent Communication, 3) Confidence, 4) honesty and 5) creativity as the five key Elements that define effective leadership ${ }^{5}$. Meanwhile, Earley $(2015)^{6}$. pinpointed 6 key component of effective leadership to include: 1) Honesty and Integrity, 2) Outstanding self-awareness, 3) vision, 4) courage, 5) Communication Skills and 6) Team Builder. To argue the case Florida Tech published on their blog page, 7 Essential Elements to Successful Leadership to comprise of: 1) Transparency, 2) Learn from failures, 3) Trust, 4) Confidence, 5) Decisiveness, 6) Humility, 7) Creativity and finally Sheninger $(2014)^{8}$ highlighted, 8 Essential Elements of Effective Leadership to include: 1) Modelling, 2) Not looking for buy-in, 3) Providing support, 4) learning from failure, 5) Transparency, 6) Flexibility, 7) Resilience, 8) Never passing the buck (decisiveness).

\section{Methodology}

The paper examines and reviews existing literature on the subject leadership and leadership elements. This constitutes the main source of data used for this paper

\footnotetext{
${ }^{3}$ http://www.businessnewsdaily.com/3647-leadership-definition.html.

${ }^{4}$ https://aboutleaders.com/successful-leadership/.

${ }^{5}$ https://www.chainreaction.org.au/article/5-key-elements-that-define-effective-leadership.

${ }^{6} \mathrm{https} / / /$ crossco.com/blog/6-key-components-effective-leadership.

${ }^{7}$ https://www.floridatechonline.com/blog/psychology/7-essential-elements-to-successful-leadership/.

${ }^{8}$ https://www.floridatechonline.com/blog/psychology/7-essential-elements-to-successful-leadership/.
} 
since it is cheap, rich in quality, well refined and readily available. Secondary and observable data were preferred over questionnaires, because the author did not perceive that questionnaires could serve a purpose for this work. To gain time secondary data was examined to serve as empirical evidence of the paper topic centered on leadership and leadership elements. Data constituting the mechanisms or channels through which leadership elements or skills are transferred (passed-on) were collected from online sources, websites and the university bulletin, presented and analysed on a table to ease understanding and a comparative table was used to present results and analyse some existing definitions for the term leadership so as to show the gap and the need for recommending another definition for leadership based on the work according to the author's view. A table was chosen to examine the type of mechanism showing the leadership elements pass on for easy display and readability, while a comparative table was selected for this work which is purely qualitative to help in benchmarking of some of the various existing definitions of leadership for quick and easy understanding and identifying the gaps in the definitions.

\section{Results and Analysis}

\subsection{The Mechanism for the Transferability of Leadership Elements to Students}

To examine CUIB's mechanism for the transferability of Leadership Skills to Students, the mechanisms channels through which leadership elements are transferred to student were examined as presented and analyzed in Table 1.

From Table 1, it shows that CUIB has sound and sufficient mechanisms for the transferability of Leadership elements to students and up to 10 leadership skills are transferred to students. This examination meets and satisfies game learn 10 points proposal on what leadership elements are comprised of. So in CUIB leadership elements transferability is a culture and it tallies with the proponent of different cultures have different moral codes (Rachels, 2002). Fallon (2015) taking from the words of Rosalynn Carter, former first lady of the United States, states that a great leader takes people where they don't necessarily want to go, but ought to be." Therefore CUIB can take people (students) and their community to where they ought to be by transferring appropriate leadership elements using its available mechanisms.

\subsection{Some Existing Definitions for the word Leadership}

Leadership is a skill used to influence followers in an organization to work enthusiastically towards goals specifically identified for the common good of all stakeholders (Barrow, 1977; Cyert, 2006; Plsek \& Wilson 2001). Leadership is, of course, subjective. But its foundation stems from one thing: the ability of an individual to establish a following among other individuals or teams. Every leader has his or her own style and strategy. Further, leadership styles and methods will differ because they are influenced by multiple factors-changing regulation, 
Table 1. Type of mechanism showing the leadership elements pass on.

\begin{tabular}{|c|c|c|c|}
\hline Mechanisms & $\begin{array}{c}\text { Type of } \\
\text { Mechanism }\end{array}$ & Mechanism Description & $\begin{array}{l}\text { Leadership Elements } \\
\text { Pass on as viewed } \\
\text { by the researcher }\end{array}$ \\
\hline 1 & $\begin{array}{l}\text { CIE Boot camp } \\
\text { Events and Awards }\end{array}$ & $\begin{array}{l}\text { Events whereby students create a business idea } \\
\text { and compete with peers before a panel. }\end{array}$ & $\begin{array}{l}\text { Entrepreneurship } \\
\text { (risk taking), visionary, } \\
\text { creativity and motivation }\end{array}$ \\
\hline 2 & $\begin{array}{c}\text { STUGA } \\
\text { Government }\end{array}$ & $\begin{array}{l}\text { STUGA stands for Student Government Association. } \\
\text { The students are elected into positions of administering } \\
\text { students' affairs over duration of one year period. }\end{array}$ & $\begin{array}{l}\text { Visionary, Serving, } \\
\text { Managing, empathy } \\
\text { and team building }\end{array}$ \\
\hline 3 & EOC Hour & $\begin{array}{l}\text { EOC is Economic of Communion, a moment of prayer } \\
\text { and sharing economic and spiritual values with others }\end{array}$ & $\begin{array}{l}\text { Team building } \\
\text { and improving }\end{array}$ \\
\hline 4 & $\begin{array}{l}\text { CUIB Talent } \\
\text { Academy }\end{array}$ & $\begin{array}{l}\text { An academy ground for students and } \\
\text { pupils to demonstrate their talents. }\end{array}$ & $\begin{array}{l}\text { Creativity } \\
\text { and Visionary }\end{array}$ \\
\hline 5 & $\begin{array}{l}\text { CUIB Sports and } \\
\text { Talent Academy }\end{array}$ & $\begin{array}{l}\text { Students are grouped according to their talents and interests } \\
\text { in various sporting activities and successful players get calls up in the } \\
\text { Cameroon Youth or National teams or foreign basketballs teams etc. }\end{array}$ & $\begin{array}{l}\text { Improving, creativity } \\
\text { and thoroughness }\end{array}$ \\
\hline 6 & $\begin{array}{c}\text { CUIB } \\
\text { Campus Church }\end{array}$ & $\begin{array}{l}\text { CUIB is graciously blessed with a campus Catholic Church parish } \\
\text { called Campus Cristo. The church welcomes students, staff, } \\
\text { faculty and their dependents on weekends and occasional week days } \\
\text { where there are trained, thought, preached and shared Christian } \\
\text { moral values and Catholic universal beliefs by a Campus based Priests. } \\
\text { The dedicated Campus Priest would counsel students on spiritual } \\
\text { and acceptable societal ethical moral values and this act } \\
\text { as a relief for students and builds confidence and trust within students. }\end{array}$ & $\begin{array}{l}\text { Serving, team building } \\
\text { and motivation }\end{array}$ \\
\hline 7 & CUIB Trade Fair & $\begin{array}{l}\text { Annually CUIB CIE (Center for Innovation and Entrepreneurship) } \\
\text { organized two weeks business trade fair event. This event is } \\
\text { opened to students and the general public with business activities } \\
\text { to hire Campus shops and employer fellow students as volunteers. }\end{array}$ & $\begin{array}{l}\text { Risk taking, serving, } \\
\text { team building, } \\
\text { Vision and Motivation }\end{array}$ \\
\hline 8 & $\begin{array}{l}\text { Student Volunteers } \\
\text { Hours Program }\end{array}$ & $\begin{array}{l}\text { Included as a semester course is the student volunteerism program. } \\
\text { These permit students to work in Campus and out campus unpaid hours } \\
\text { where working attitude and professional ethics are passed on to students. }\end{array}$ & Serving, team building \\
\hline
\end{tabular}

Table 2. A comparative table of some existing leadership definitions.

\begin{tabular}{|c|c|c|c|c|}
\hline $\mathrm{S} / \mathrm{N}$ & Author & Author's Profession & Definition of leadership & Gaps Identified \\
\hline 1 & $\begin{array}{l}\text { (Barrow, 1977; } \\
\text { Cyert, 2006; } \\
\quad \text { Plsek \& } \\
\text { Wilson, 2001) }\end{array}$ & Researchers & $\begin{array}{l}\text { Leadership is a skill used to influence followers } \\
\text { in an organization to work enthusiastically } \\
\text { towards goals specifically identified } \\
\text { for the common good of all stakeholders }\end{array}$ & $\begin{array}{l}\text { By "a skill" means that it is } \\
\text { enough for a leader to possess } \\
\text { and demonstrate freely } \\
\text { just one leadership element }\end{array}$ \\
\hline 2 & Samantha Cohen & co-founder, Neon Bandits & $\begin{array}{l}\text { Leadership is about playing to strengths and } \\
\text { addressing weaknesses in the most productive } \\
\text { and efficient way possible. It's about } \\
\text { knowing your team and yourself, and doing } \\
\text { your best job to set both up for success }\end{array}$ & $\begin{array}{l}\text { Leadership is more than } \\
\text { management of strengths, weak- } \\
\text { nesses, people and self. What } \\
\text { about opportunities } \\
\text { and threats? }\end{array}$ \\
\hline 3 & Jordan French & $\begin{array}{c}\text { founding CMO, BeeHex, } \\
\text { Inc. 3D Food Printing, }\end{array}$ & $\begin{array}{l}\text { Leadership is serving the people that work for } \\
\text { you by giving them the tools they need to succeed. } \\
\text { Your workers should be looking forward to the } \\
\text { customer and not backwards, over their shoulders, } \\
\text { at you. It also means genuine praise for } \\
\text { what goes well, leading by taking responsibility } \\
\text { early and immediately if things go bad }\end{array}$ & $\begin{array}{l}\text { Leadership should be } \\
\text { more than serving, } \\
\text { praise and taking } \\
\text { responsibility }\end{array}$ \\
\hline 4 & Darcy Eikenberg & $\begin{array}{c}\text { Founder } \\
\text { RedCapeRevolution.com }\end{array}$ & $\begin{array}{l}\text { A leader is someone who has the clarity to know the } \\
\text { right things to do, the confidence to know } \\
\text { when she's wrong, and the courage to } \\
\text { do the right things even when they're hard }\end{array}$ & $\begin{array}{l}\text { Leadership should be } \\
\text { more than clarity, } \\
\text { confidence and courage }\end{array}$ \\
\hline
\end{tabular}


digitalization and technology, globalization, innovation, financial markets, recruiting and retaining talents, industry, profession, environment, the company specific factors, company size of the business or organization. A comparative table of some definitions for Leadership is presented in Table 2.

From Table 2, reading through the analysis, on the Gaps Identified it shows that all four leadership definitions analyzed as presented require improvement and one could conclude that there exist no standard definitions for the term leadership; hence the need for one should be just so imperative.

\subsection{Main Findings}

A university is a ground that possesses, demonstrates and transfers (pass-on) leadership elements (skills) to students. Thus Universities should be responsible for growing and training next generation of good and complete or perfect leaders better than any institution. Graciously blessed Catholic University Institute of Buea (CUIB) has sound and sufficient mechanisms, tools, or channels to transfer (pass-on) leadership elements to students. Therefore CUIB can take people (students) and their community to where they ought to be by transferring appropriate leadership elements using its available mechanisms thus making those around better, among others, a quality a great leader possesses Fallon $(2016,2017)$. However continuous improvement and the creation of new channels are required such that a single channel can be able to transfer at least 6 leadership elements if they hope to produce complete leaders to maintain and sustain the mission of the university to prepare professional servant leaders with moral and spiritual values, who will contribute to the sustainable development of their communities.

There is no standard definition for the word leadership, some have defined leadership in terms of the leadership element(s) a leader has or should have while others have defined it based on what a leader does or leaders do and forgot that there is a possibility for one to be a bad leader and as such it would be difficult to pass-on the bad in them, since no one like bad things. In another hand one could be considered a bad leader if s/he possesses and demonstrates just one dominant leadership skill or element such a leader will be near autocratic as some have defined leadership and limited leadership to a skill. As such the existing definitions for the term leadership require an improvement or rather the need for one is imperative.

Since there exist no standard definitions for the word leadership, the rethinking of the possibility of a genuine grading and classification system for leaders based on the leadership elements they possess and demonstrate does not exist. It is imperative to have such a scale to facilitate leaders' benchmarking, comparative studies and analysis.

\section{Conclusion}

From the findings, the following recommendations could be deduced: 
1) For continuous improvement, a University should keep on creating new channels and improving mechanisms required to transfer leadership elements such that a single channel can be able to transfer at least 6 leadership elements if they hope to produce complete leaders to maintain and sustain the mission of the university to prepare professional servant leaders with moral and spiritual values, who will contribute to the sustainable development of their communities. For reason that one cannot stay in the University forever, Individuals, Organizations and Societies should have programs, activities, channels or mechanisms for cultivating and passing on leadership elements to heirs of the next generation for future successful organizational, economic and societal development and advancement for the wellbeing of all.

2) The word leadership should have a standard or a universal definition even though each leader has his or her own strategy but leaders should generally possess, demonstrate and pass on some common elements if they are to be successful. Based on this, the definition of Leadership which states that "Leadership is a skill used to influence followers in an organization to work enthusiastically towards goals specifically identified for the common good of all stakeholders" (Barrow, 1977; Cyert, 2006; Plsek \& Wilson, 2001) could be improved to "Leadership is a representation or set of skills used to influence followers in an organization to work enthusiastically towards goals specifically identified for the common good of all stakeholders". Otherwise, a new definition proposal for leadership could be "Leadership is the representation of the abilities to do things good differently or exemplary and pass on elements, skills, principles, experience, values, wealth and talents to heirs for the wellbeing of individuals, organizations and the society as a whole".

3) The aforementioned improved and/or new proposed definition would enhance comparative studies and analysis to facilitate benchmarking of leaders based on the leadership elements they possess and demonstrate freely. Thus Leaders or Leadership should be graded as either complete leader (total or perfect leadership) if they possess all the 10 elements of leadership or at least 6 elements of a leader (leadership), or partial or good leader (leadership) if they possess more than 2 but at most 5 of the elements of a leader (leadership) and a bad leader, if they possess just 1 of the leadership elements. In order words, you are a perfect or excellent leader if you possess at least 6 or all the elements. A good leader should have between 2 to 5 elements and a bad leader has 1 element. A leader with one dominant leadership element will be a near if not autocratic leader. Such classification of leaders as perfect/excellent, good or bad would facilitate comparing leaders irrespective of organization, industry, country or society they operate in or lead and even current and previous presidents of countries could be compared easily based on the leadership elements they possess and demonstrate easily.

To conclude, upon examination of the leadership elements, one could agree that CUIB is a complete leader in transferring leadership skills or elements to 
students. An improvement or a new way of defining leadership is required to take into cognizance the leadership elements leaders possess and demonstrate freely. The improved definition "Leadership is a representation or a set of skills used to influence followers in an organization to work enthusiastically towards goals specifically identified for the common good of all stakeholders", and the new proposal "Leadership is the representation of the abilities to do things good differently or exemplary and pass on elements, skills, principles, experience, values, wealth and talents to heirs for the wellbeing of individuals, organizations and the society as a whole", should be adopted for academic, professional and research purposes.

\section{References}

Aronson, E. (2001). Integrating Leadership Styles and Ethical Perspectives. Canadian Journal of Administrative Sciences, 18, 244-256. https://doi.org/10.1111/j.1936-4490.2001.tb00260.x

Banutu-Gomez, M. B., \& Banutu-Gomez, S. M. T. (2007). Leadership and Organizational Change in a Competitive Environment. Business Renaissance Quarterly, 2, 69-91.

Barrow, J. C. (1977). The Variables of Leadership. Academy of Management Review, 2, 231-251. https://doi.org/10.5465/amr.1977.4409046

Bass, B. M., \& Bass, R. (2008). The Bass Handbook of Leadership: Theory, Research, and Managerial Applications. New York: The Free Press.

Bell, M. (2016). Key Elements that Define Effective Leadership, Chain Reaction Foundation Ltd.

https://www.chainreaction.org.au/article/5-key-elements-that-define-effective-leadersh ip

CUIB, 2015-2016 Bulletin.

Cyert, R. M. (2006). Defining Leadership and Explicating the Process. Nonprofit Management and Leadership, 1, 29-38. https://doi.org/10.1002/nml.4130010105

Dickson, M. W., Smith, D. B., Grojean, M. W., \& Ehrhart, M. (2001). An Organizational Climate Regarding Ethics: The Outcome of Leader Values and the Practices that Reflect Them. The Leadership Quarterly, 12, 197-217. https://doi.org/10.1016/S1048-9843(01)00069-8

Earley, S. (2015). 6 Key Components to Effective Leadership. Cross. https://crossco.com/blog/6-key-components-effective-leadership

Elçi, M., Şener, I., \& Alpkan, L. (2013). The Impacts of Ethical Leadership on the Antisocial Behavior of Employees: The Mediating Role of Ethical Climate. Journal of Global Strategic Management, 7, 57-66.

Fallon, N. (2017). 8 Ways to Become a Better Leader. Business News Daily. https://www.businessnewsdaily.com/4991-effective-leadership-skills.html

Fallon, N. (2015). 35 Inspiring Leadership Quotes. Business News Daily. http://www.businessnewsdaily.com/7481-leadership-quotes.html

Fallon, N. (2016). What Makes a Great Leader? Business News Daily. http://www.businessnewsdaily.com/2730-leadership.html

Florida Tech. 7 Essential Elements to Successful Leadership. https://www.floridatechonline.com/blog/psychology/7-essential-elements-to-successful -leadership/ 
Game Learn (2016). What Is Leadership? 10 Ways to Define It. https://www.game-learn.com/what-is-leadership-ways-to-define/

Jose, A., \& Thibodeaux, M. S. (1999). Institutionalization of Ethics: The Perspective of Managers. Journal of Business Ethics, 22, 133-143. https://doi.org/10.1023/A:1006027423495

Kotter, J. P. (2001). What Leaders Really Do. Harvard Business Review, 79, 85-98.

Mayer, D. M., Kuenzi, M., \& Greenbaum, R. L. (2010). Examining the Link between Ethical Leadership and Employee Misconduct: The Mediating Role of Ethical Climate. Journal of Business Ethics, 95, 7-16. https://doi.org/10.1007/s10551-011-0794-0

Mendonca, M. (2001). Preparing for Ethical Leadership in Organizations. Canadian Journal of Administrative Sciences, 18, 266-276. https://doi.org/10.1111/j.1936-4490.2001.tb00262.x

Miller, M. The 5 Ways to Define Leadership. Emergenetics International. https://www.emergenetics.com/blog/5-ways-define-leadership/

Murphy, P. (2015). 4 Essential Elements of Successful Leadership. About Leaders. https://aboutleaders.com/successful-leadership/

Neubert, M. J., Carlson, D. S., Kacmar, K. M., Roberts, J. A., \& Chonko, L. B. (2009). The Virtuous Influence of Ethical Leadership Behavior: Evidence from the Field. Journal of Business Ethics, 90, 157-170. https://doi.org/10.1007/s10551-009-0037-9

Nso, M. A., \& Ngatchu, D. (2017). The Effect of Ethical Leadership on a University's Success and Its Transfer to Students: The Case of the Catholic University Institute of Buea (CUIB), Managing and Teaching Business Ethics: Global Trends and Challenges.

Parris, D. L., \& Peachey, J. W. (2013). A Systematic Literature Review of Servant Leadership Theory in Organizational Contexts. Journal of Business Ethics, 113, 377.

Plsek, P. E., \& Wilson, T. (2001). Complexity, Leadership, and Management in Healthcare Organisations. BMJ, 323, 746-749. https://doi.org/10.1136/bmj.323.7315.746

Post, J. (2017). 11 Ways to Define Leadership. Business News Daily. http://www.businessnewsdaily.com/3647-leadership-definition.html

Rachels, J. (2002). Elements of Moral Philosophy. New York, NY: McGraw Hill Higher Education.

Ronald, D. F. (2013). The Effects of Ethical Leadership and Organizational Safety Culture on Safety Outcomes (p. 55). Dissertations and Theses.

https://commons.erau.edu/edt/55

Schein, E. (1985). Organizational Culture and Leadership. San Francisco, CA: Jossey-Bass.

Schminke, M., Ambrose, M., \& Neubaum, D. (2005). The Effect of Leader Moral Development on Ethical Climate and Employee Attitudes. Organizational Behavior and Human Decision Processes, 97, 135-151. https://doi.org/10.1016/j.obhdp.2005.03.006

Schneider, B. (1987). The People Make the Place. Personnel Psychology, 40, 437-453. https://doi.org/10.1111/j.1744-6570.1987.tb00609.x

Sheninger, E. (2014). Essential Elements of Effective Leadership. BLOG, HUFFPOST. http://www.huffingtonpost.com/eric-sheninger/effective-leadership_b_4238789.html

Sims, R. R. (2000). Changing an Organization's Culture under New Leadership. Journal of Business Ethics, 25, 65-78. https://doi.org/10.1023/A:1006093713658

Sims, R. R., \& Brinkman, J. (2002). Leaders as Moral Role Models: The Case of John Gutfreund at Salomon Brothers. Journal of Business Ethics, 35, 327-339.

https://doi.org/10.1023/A:1013826126058 
Thornton, L. F. (2013). 7 Lenses: Learning the Principles and Practices of Ethical Leadership. Richmond, VA: Leading in Context.

Treviño, L. K., Hartman, L. P., \& Brown, M. (2000). Moral Person and Moral Manager: How Executives Develop a Reputation for Ethical Leadership. California Management Review, 42, 128-142. https://doi.org/10.2307/41166057 